\title{
IV. Notes and News.
}

Falconry.-With reference to the recent correspondence in our Journal on this subject, it may be noted that Medbātitli (who probably lived in the ninth century in Kashmīr) thinks that the author of Manu, iii, 162, is there referring to trainers of hunting falcons and hawks.

Paris Oriental Congress. - As already announced, the Congress will be held Sept. 5-12. The subscription (16s. for men, 8s. for ladies) can be paid, and tickets procured, from Mr. Luzac, 46, Great Russell Street, London, W.C. We trust that as many as possible of our members and their friends will attend this Congress, which promises to be a great success. Communications regarding papers to be read at the Congress may be addressed to the President, M. Charles Schefer, 2, Rue de Lille, Paris, or to the Hon. Secretaries of the various sections.

A special Committee of members of the Society has been formed to deal with any questions that may arise in connection with the Congress. The members of that Committee at present are Mr. F. F. Arbuthnot, Professor Bendall, Dr. Cust, Dr. Leitner, Mr. Robert Sewell, and Dr. Thornton, with Professor Rhys Davids as secretary. The President of the Society, who takes an especial interest in the Congress, and has also consented to serve as one of the Society's delegates to it, is ex-officio President also of the Committee.

The following gentlemen have been asked to represent the Society as its delegates to the Congress, and those marked with an asterisk have signified their acceptance :-

*The President.

Vice-Presidents $\{$ *Professor Sayce. of the Society. $\{*$ Sir Raymond West.

From
Cambridge. $\quad\left\{\begin{array}{l}\text { Mr. Edward G. Browne. } \\ \text { Professor Cowell. }\end{array}\right.$



From
Oxford. $\quad\left\{\begin{array}{l}* \text { Professor Macdonell. } \\ * \text { Professor Margoliouth. }\end{array}\right.$
From the $\left\{\begin{array}{l}* \text { Professor Douglas. } \\ \text { itish Museum. }\end{array}\right.$
From the Indian ${ }^{*}$ Mr. Robert Sewell.
Civil Service. $\{$ Mr. Fleet.
To represent the
Council. $\left\{\begin{array}{l}\text { Mr. H. O. Kay. } \\ * \text { Professor T. W. Rhys Davids. }\end{array}\right.$

We hope in our next issue to be able to give a preliminary list of all the papers to be read. At present we can only say that English scholarship will be well represented at the Congress, both by personal participation and reading of papers.

Notice to Members.-Our present List of Members gives in many instances only the initials of the name, and omits in others the degrees held or the offices filled by members. The Council, thinking it advisable to amend the list in these particulars, would be obliged to any member who would be so good as to supply such information as may be necessary for the next issue of the list, to be corrected accordingly; and where names are Oriental, the Council would urge upon their members the desirability of conforming as far as possible with the scheme of transliteration as agreed upon by the Geneva Congress and reproduced in our own issue of October last.

Transliteration.-As Bible and Missionary Societies are frequently publishing translations, and also primers, vocabularies, and grammars-often of languages that have not hitherto had an alphabet-the report of this Society on the Scheme of Transliteration adopted by the Geneva Congress of Orientalists has been brought to their notice by Dr. Cust and Mr. Henry Morris, with the result that the following Societies have passed resolutions in which the 
Scheme is recommended to the notice of authors writing under their auspices :-

1. The British and Foreign Bible Society.

2. The National Bible Society for Scotland.

3. The Society for Promoting Christian Knowledge.

4. The Religious Tract Society.

5. The Baptist Bible Translation Society.

6. The Society for the Propagation of the Gospel in Foreign Parts.

7. The Church Missionary Society.

8. The South American Missionary Society.

9. The Universities' Mission to East Africa.

10. The London Missionary Society.

11. The Wesleyan Missionary Society.

12. The Moravian Mission.

13. The Christian Literature Society for India.

Päli Text Society.-Professor Edmond Hardy has completed his edition of Dhammapāla's Commentary on the Peta Vatthu for this Society. The following works are also passing through the Press:-

Kathā Vatthu, edited by Mr. A. C. Taylor.

Majjhima Nikāya, vol. ii, edited by Mr. Robert Chalmers.

Attha Sălinĩ, edited by Professor E. Müller.

Index to Gandha Vamsa, by Mrs. Bode.

Samādhi and Jhāna, edited by Professor Rhys Davids.

Anguttara, vol. iii, edited by Professor Edmond Hardy.

Samyutta, vol. v, edited by M. Léon Feer.

Mrs. Bode has an edition of the Sāsana Vamsa ready for the Press, and is preparing a translation of the same work. 
Half-yearly Philology Notes. Part II, 1897.

\author{
I. Asia. \\ II. Africa. \\ III. Oceania. \\ IV. America.
}

\title{
I. Asia.
}

By the favour of Professor Donner, of Helsingfors, and Professor Radloff, of St. Petersburg, I have in late years received six pamphlets on the Inscriptions found in Siberia in an alphabet peculiar to itself, though no doubt descended from the common Mother Alphabet, the Phenician, of which the oldest specimen is the Moabite Stone in the ninth century before the Christian era. As scholars have a difficulty in finding the names of works published in a foreign country, I enumerate them chronologically :

1. Inscriptions de Jenissei, Siberie, N. Russie: par J. L. Aspelin. Helsingfors, 1889.

2. Wörterverzeichniss zu den Inschriften der Jenissei : von O. Donner. Helsingfors, 1892.

3. Antiquités de la Siberio Occidentale: par Axel Heikel. Helsingfors, 1894.

4. Altturkischen Inschriften der Mongolei: von W. Radloff. St. Petersburg, 1894.

5. Inscriptions de l'Orkhon, dechiffrées par Vilh. Thomsen. Helsingfors, 1894.

6. Sur l'origine de l'Alphabet Ture du Nord de l'Asie: par O. Donner. Helsingfors, 1896.

The subject is very intricate, and we have by no means yet heard the last word, and no opinion is ventured upon.

Satsaya of Bikâri, with a Commentary, edited by Mr. Grierson, Indian Civil Service, M.R.A.S. 
Notes on Oukong's Account of Kashmir, by Dr. Stein, of the Lahor College.

The contribution of Professor J. S. Speyer, of Groningen, deals in a very thorough manner with Vedic and Sanskrit syntax. The two periods of ancient Indian syntax have been treated separately by Professor Delbrück and Professor Speyer respectively. In the present volume they are for the first time treated in connection, so that they can here be studied from a historical point of view. The work is divided into two parts: the first deals with the syntactical employment of the noun, the verb, and particles, while the second is concerned with the structure of the various forms of the sentence and the period.

Professor R. Garbe, of Tübingen, the author of the most important work hitherto published on the Sānkhya philosophy, treats of the closely allied Sānkhya and Yoga systems. The first part of the contribution (pp. 1-33) really represents the contents of his larger work on the Sankhya in outline, with such modifications as criticism has suggested since its publication in 1894. The author shows that the Sankhya doctrines are pre-Buddhistic, and are, in fact, the chief source of the theoretical part of Buddhism. He further points out that practically the whole of the Sānkbya doctrines are to be found in the Mahābhārata, which is actually our oldest source for these doctrines. The deviations it contains from the statements of the chronologically later textbooks of the system, are, he insists, secondary; and the Mahäbhārata is therefore of less value as a source than those treatises. The second part of the book (pp. 33-52) deals with the Yoga philosophy, which in reality differs from the Sānkhya only in rejecting the atheism of the latter. The contribution contains some interesting information about the extraordinary hypnotic powers acquired by Yogis through the practice of a system of asceticism so elaborate, that it recognizes no less than 84 different sitting postures, as conducive to mental concentration. 


\section{Africa.}

Jacotet on South African Languages.-The well-known Oriental publisher, Ernest Leroux, of 28, Rue Bonaparte, Paris, has, in 1896, published an important contribution to African Philology, under the title of "Études sur les langues de Haut Zambéze": Original Texts, and a Grammatical Sketch by E. Jacotet, a French Missionary of the Evangelical Missionary Society of Paris. The first Part has been presented to me by the author, who called upon me in September: this part embraces Grammatical Sketches on the "Subiya" and "Luyi." The compiler is a Missionary in Ba-Suto land, but he had the assistance of three young inhabitants of the Zambesi Valley: the words were caught from their mouths, transferred to paper, and then carefully revised by them; these young men had come to Thaba-Bosiu (the headquarters of the French Mission) to be educated. The languages belong to the great South African or Bantu Linguistic Family. The study of the two languages is most useful to linguistic students, but a perusal of the Introductory chapter, pp. vii to xxxvii, would be interesting and instructive to the general reader.

Zeitschrift für Afrikanische und Oceanische Sprachen, 2nd year, 4th part, December, 1896, entirely occupied by a Grammar in the French Language by a G. de Beers, a Missionary on the Kongo, of the Tabwa Language in that region.

\section{Oceania.}

Mr. Sidney Ray, the representative of our knowledge of the Languages of Oceania, has contributed to the Journal of the Anthropological Institute a "Vocabulary and Grammatical Note" on the Languages of Makura, Central New Hebrides.

He has also contributed to the Journal of the Polynesian Society an important Essay on the "Common Origin of 
the Oceanic Languages." Here he is venturing upon a very great enterprise, and it cannot be assumed, that all will agree with him. $\mathrm{He}$ seems to include the Languages of the Malay Archipelago, under the name of Indonesian, into this category. Among the Languages mentioned in this division he includes what some students unhesitatingly include among the Languages of the East Indies. However, the subject is an interesting one, and the next generation will be able to arrive at a more certain opinion.

\section{America.}

(1) Linguae Guárani Grammatica and (2) Lexicon Hispano-Guaranicum, a Rev. patre Jesuita Paulo Restivo, secundum libros Antonii Ruiz de Montoya denuo edita et adaucta opera et studiis Ch. Fred. Seybold. (Stuttgardt: William Kohlhammer.)

Dr. Seybold's new and enlarged editions of the works of the Rev. Jesuit have been added to the Library. The circle of readers to whom they are addressed, those who combine a wish to study the Guárani language with a good knowledge of Spanish, is a small one, but that very fact will probably lead to a warmer appreciation of their value on the part of those who can use them. We trust that such members of our Society will not be slow to avail themselves of Dr. Seybold's painstaking and valuable labours, for the presence of such books in our Library is an important evidence of the cosmopolitan character of the Society, and the wide extent of its aims.
January 21, 1897.
R. N. C.

\section{Additions to the Library.}

Presented by the India Office.

Cox (Captain P. Z.). Genealogies of the Somál, including those of the Äysa and Gadabürsi, compiled by Major H. M. Abud.

Folio. London, 1896. 